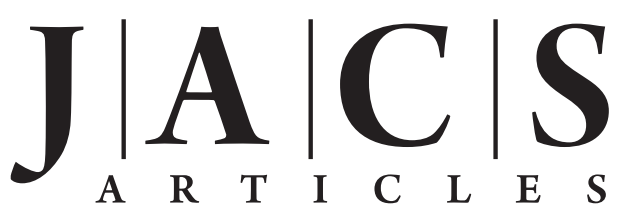

Published on Web 09/29/2009

\title{
Small and Stable Peptidic PEGylated Quantum Dots to Target Polyhistidine-Tagged Proteins with Controlled Stoichiometry
}

\author{
Aurélien Dif, ${ }^{\dagger}$ Fouzia Boulmedais, ${ }^{\dagger}{ }^{\S}$ Mathieu Pinot, ${ }^{\ddagger}$ Victor Roullier, ${ }^{\dagger}$

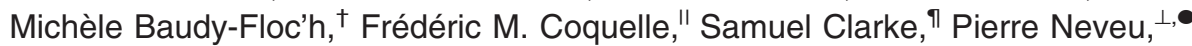 \\ Françoise Vignaux, ${ }^{\square}$ Roland Le Borgne, ${ }^{\square}$ Maxime Dahan, ${ }^{"}$ Zoher Gueroui, ${ }^{\ddagger}$ and \\ Valérie Marchi-Artzner ${ }^{*} \dagger$ \\ Université de Rennes 1, CNRS UMR 6226, Sciences Chimiques de Rennes, Rennes, France, \\ Université de Rennes 1, CNRS UMR 6251, Institut de Physique de Rennes, France, Université de \\ Rennes 1, CNRS UMR 6026, IFR 140, Rennes, France, Institut Charles Sadron, CNRS UPR 22, \\ Strasbourg, France, Ecole Normale Supérieure, CNRS UMR 8640, Département de Chimie, France, \\ Laboratoire Kastler Brossel, Ecole Normale Supérieure, CNRS UMR 8552, Université Pierre et \\ Marie Curie, Paris 6, France, and Université Rennes 1, CNRS UMR 6061-faculté de médecine, \\ Rennes, France
}

Received April 6, 2009; E-mail: valerie.marchi-artzner@univ-rennes1.fr

\begin{abstract}
The use of the semiconductor quantum dots (QD) as biolabels for both ensemble and singlemolecule tracking requires the development of simple and versatile methods to target individual proteins in a controlled manner, ideally in living cells. To address this challenge, we have prepared small and stable QDs (QD-ND) using a surface coating based on a peptide sequence containing a tricysteine, poly(ethylene glycol) (PEG), and an aspartic acid ligand. These QDs, with a hydrodynamic diameter of $9 \pm 1.5 \mathrm{~nm}$, can selectively bind to polyhistidine-tagged (histag) proteins in vitro or in living cells. We show that the small and monodisperse size of QD-ND allows for the formation of QD-ND/histag protein complexes of well-defined stoichiometry and that the 1:1 QD/protein complex can be isolated and purified by gel electrophoresis without any destabilization in the nanomolar concentration range. We also demonstrate that QD-ND can be used to specifically label a membrane receptor with an extracellular histag expressed in living HeLa cells. Here, cytotoxicity tests reveal that cell viability remains high under the conditions required for cellular labeling with QD-ND. Finally, we apply QD-ND complexed with histag end binding protein-1 (EB1), a microtubule associated protein, to single-molecule tracking in Xenopus extracts. Specific colocalization of QD-ND/EB1 with microtubules during the mitotic spindle formation demonstrates that QD-ND and our labeling strategy provide an efficient approach to monitor the dynamic behavior of proteins involved in complex biological functions.
\end{abstract}

\section{Introduction}

The development of simple coupling methods to visualize, track and eventually activate proteins using fluorescent labels in living cells is a key step in cellular imaging. ${ }^{1-6}$ Although fluorescent proteins have revolutionized this field, they have

†Université de Rennes 1, CNRS UMR 6226, Sciences Chimiques de Rennes.

¥Université de Rennes 1, CNRS UMR 6251, Institut de Physique de Rennes.

$\S^{\S}$ Institut Charles Sadron, CNRS UPR 22.

"Université de Rennes 1, CNRS UMR 6062, IFR 140.

${ }^{\perp}$ Ecole Normale Supérieure, CNRS UMR 8640, Département de Chimie.

"Laboratoire Kastler Brossel, Ecole Normale Supérieure, CNRS UMR 8552, Université Pierre et Marie Curie.

Université de Rennes 1, CNRS UMR 6061, Faculté de Médecine.

- Present address: Kavli Institute for Theoretical Physics, University of California at Santa Barbara.

(1) Marks, K. M.; Nolan, G. P. Nat. Methods 2006, 3 (8), 591-596.

(2) Johnsson, N.; Johnsson, K. ACS Chem. Biol. 2007, 2 (1), 31-38.

(3) Giepmans, B. N. G.; Adams, S. R.; Ellisman, M. H.; Tsien, R. Y. Science. 2006, 312, 217-224.

(4) Miller, L. W.; Cornish, V. W. Curr. Opin. Chem. Biol. 2005, 9 (1), $56-61$.

(5) Chen, I.; Ting, A. Y. Curr. Opin. Chem. Biotechnol. 2005, 16 (1), $35-40$. shortcomings, such as rapid photobleaching of the chromophores and the requirement of genetically modified proteins, which have necessitated the development of alternative approaches to chemically label proteins in live cells. ${ }^{3,7}$ In this view, fluorescent semiconductor nanocrystal quantum dots (QDs) have received considerable attention because of their unique optical properties, which are well suited for biological imaging. ${ }^{8-10}$ Many strate-

(6) Bonasio, R.; Carman, C. V.; Kim, E.; Sage, P. T.; Love, K. R.; Mempel, T. R.; Springer, T. A.; von Andrian, U. H. Proc. Natl. Acad. Sci. U.S.A. 2007, 104 (37), 14753-14758.

(7) Howarth, M.; Takao, K.; Hayashi, Y.; Ting, A. Y. Proc. Natl. Acad. Sci. U.S.A. 2005, 102 (21), 7583-7588.

(8) Michalet, X.; Pinaud, F. F.; Bentolila, L. A.; Tsay, J. M.; Doose, S.; Li, J. J.; Sundaresan, G.; Wu, A. M.; Gambhir, S. S.; Weiss, S. Science 2005, 307 (5709), 538-544.

(9) Agrawal, A.; Deo, R.; Wang, G. D.; Wang, M. D.; Nie, S. Proc. Natl. Acad. Sci. U.S.A. 2008, 105 (9), 3298-3303.

(10) Dahan, M.; Levi, S.; Luccardini, C.; Rostaing, P.; Riveau, B.; Triller, A. Science 2003, 302 (5644), 442-445.

(11) Susumu, K.; Uyeda, H. T.; Medintz, I. L.; Pons, T.; Delehanty, J. B.; Mattoussi, H. J. Am. Chem. Soc. 2007, 129 (45), 13987-13996.

(12) Nehilla, B. J.; Vu, T. Q.; Desai, T. A. J. Phys. Chem. B 2005, 109 (44), 20724-20730.

(13) Iyer, G.; Michalet, X.; Chang, Y.-P.; Pinaud, F. F.; Matyas, S. E.; Payne, G.; Weiss, S. Nano Lett. 2008, 8 (12), 4618-4623. 
gies have now been described to obtain bioconjugated QD probes, including both covalent or noncovalent interactions of proteins or other biomolecules at the QD surface. These include specific recognition system such as streptavidin/biotin, ${ }^{7,11,12}$ antibody-antigen recognition, ${ }^{13}$ or electrostatic interactions. ${ }^{14}$ General concerns in all these methods are the final size of the bioconjugate, ${ }^{15,16}$ the multivalency of the conjugation, and the preservation of protein functionality. ${ }^{17}$ Since the size of a QD is comparable or greater than the size of many proteins, it is technically difficult to separate QD/protein complexes with different stoichiometries. Only recently, it was reported that gel electrophoresis can be used to isolate QD/streptavidin/antibody complexes with $1: 1$ stoichiometry. $^{18}$

To target a specific site on a protein of interest, one strategy is to introduce a small fusion $\operatorname{tag}^{19}$ such as a polyhistidine peptide sequence (histag). This tag, commonly used for purification, contains six (H6) or ten histidines (H10) and exhibits a high affinity for divalent nickel $\left(\mathrm{Ni}^{2+}\right)$ or zinc $\left(\mathrm{Zn}^{2+}\right)$ ions. Previously, we reported the preparation of QD-micelles bearing a tris-nitrilotriacetic acid (trisNTA) ligand to target histag proteins by high-affinity complexation via $\mathrm{Ni}^{2+}$ ions. ${ }^{20}$ However, a possible limitation of these QD-micelles is that their hydrodynamic diameter is between 20 to $30 \mathrm{~nm}$ following complexation with the histag protein. Since intracellular trafficking of nanoparticles ${ }^{21}$ and their access to crowded cellular environments $^{22}$ are strongly influenced by their size, it is important to develop strategies in order to reduce the overall size of QD/ protein complexes. One effective route has been the use of compact surface coatings which enable the direct binding of histag proteins to exposed or accessible $\mathrm{Zn}^{2+}$ ions at the surface of $\mathrm{CdSe} / \mathrm{ZnS}$ QDs. ${ }^{23-26}$ For this purpose, PEGylated dihydrolipoic acid (DHLA) has been shown to facilitate the direct interaction of histag proteins with the QD surface. ${ }^{18,27,28}$ Using

(14) Mattoussi, H.; Mauro, J. M.; Goldman, E. R.; Anderson, G. P.; Sundar, V. C.; Mikulec, F. V.; Bawendi, M. G. J. Am. Chem. Soc. 2000, 122 (49), 12142-12150.

(15) Choi, H. S.; Liu, W.; Misra, P.; Tanaka, E.; Zimmer, J. P.; Ipe, B. I.; Bawendi, M. G.; Frangioni, J. V. Nat. Biotechnol. 2007, 25 (10), 11651170.

(16) Swift, J. L.; Cramb, D. T. Biophys. J. 2008, 95 (2), 865-876.

(17) Resch-Genger, U.; Grabolle, M.; Cavaliere-Jaricot, S.; Nitschke, R.; Nann, T. Nat. Methods 2008, 5 (9), 763-775.

(18) Howarth, M.; Liu, W.; Puthenveetil, S.; Zheng, Y.; Marshall, L. F.; Schmidt, M. M.; Wittrup, K. D.; Bawendi, M. G.; Ting, A. Y. Nat. Methods 2008, 5, 397-399.

(19) O'Hare, H. M.; Johnsson, K.; Gautier, A. Curr. Opin. Struct. Biol. 2007, 17 (4), 488-494.

(20) Roullier, V.; Clarke, S.; You, C.; Pinaud, F.; Gouzer, G.; Schaible, D.; Marchi-Artzner, V.; Piehler, J.; Dahan, M. Nano Lett. 2009, 9 (3), 1228-1234.

(21) Tekle, C.; van Deurs, B.; Sandvig, K.; Iversen, T. G. Nano Lett. 2008, 8 (7), 1858-1865.

(22) Groc, L.; Lafourcade, M.; Heine, M.; Renner, M.; Racine, V.; Sibarita, J. B.; Lounis, B.; Choquet, D. L. C. J. Neurosci. 2007, 27 (46), 124337.

(23) Sapsford, K. E.; Pons, T.; Medintz, I. L.; Higashiya, S.; Brunel, F. M.; Dawson, P. E.; Mattoussi, H. J. Phys. Chem. C 2007, 111 (31), 1152811538.

(24) Medintz, I. L.; Berti, L.; Pons, T.; Grimes, A. F.; English, D. S.; Alessandrini, A.; Facci, P.; Mattoussi, H. Nano Lett. 2007, 7, 17411748 .

(25) Medintz, I. L.; Sapsford, K. E.; Clapp, A. R.; Pons, T.; Higashiya, S.; Welch, J. T.; Mattoussi, H. J. Phys. Chem. B 2006, 110 (22), $10683-$ 10690 .

(26) Liu, W.; Howarth, M.; Greytak, A. B.; Zheng, Y.; Nocera, D. G.; Ting, A. Y.; Bawendi, M. G. J. Am. Chem. Soc. 2008, 130 (4), 12741284.

(27) Delehanty, J. B.; Medintz, I. L.; Pons, T.; Brunel, F. M.; Dawson, P. E.; Mattoussi, H. Bioconjugate Chem. 2006, 17 (4), 920-927.

(28) Medintz, I. L.; Goldman, E. R.; Lassman, M. E.; Mauro, J. M. Bioconjugate Chem. 2003, 14 (5), 909-918. the DHLA strategy, QD/protein complexes exhibit a reduced size (hydrodynamic diameter $\sim 15 \mathrm{~nm}$ ) in comparison to QDs with amphiphilic molecule $(\sim 20-30 \mathrm{~nm})^{29-31}$ or polymer-based $(\sim 20-30 \mathrm{~nm})^{32}$ surface coatings.

In the present work, we report a simple alternative for labeling individual histag proteins with QDs while maintaining a small $\mathrm{QD} /$ protein complex size. We selected short peptides to stabilize the QDs in aqueous buffers because of their good chemical versatility as well as their higher chemical stability compared with QD coatings formed with ester bonds. ${ }^{33,34}$ Peptides also have the advantage that it is easy to introduce biologically active sequences as terminal groups and they can be obtained from commercial providers, eliminating the need for complex or timeconsuming chemical synthesis and characterization. Peptides derived from the phytochelatin were first demonstrated to be a very effective surface coating, yielding water-soluble QDs with hydrodynamic diameters of $\sim 10-15 \mathrm{~nm} .{ }^{35}$ We have found that small tricysteine peptide derivatives, such as the sequence CCCSSSD, can also interact strongly with the QD surface and serve to form stable water-soluble QDs with a hydrodynamic diameter of $\sim 10 \mathrm{~nm}^{36}$ On the basis of these results, we prepared small QDs based on peptide ND, composed of a tricysteine adhesive group, a hexamer of PEG, and an aspartic acid grafted to the terminal group. We show that for these QD-ND, the PEG spacer effectively prevents nonspecific adsorption on cell membranes and that the probe is nontoxic to cells under standard experimental conditions. Furthermore, specific binding of histag proteins is mediated by binding to $\mathrm{Zn}^{2+}$ ions directly accessible on the QD surface and possibly enhanced by the metal-chelating dicarboxylate acid functionality of the aspartic acid.

Through application of QD-ND, we demonstrate the ability to label and track histag proteins both in vitro and in living cells. In vitro, we show evidence from dynamic light scattering (DLS) and fluorescence correlation spectroscopy (FCS) measurements that the QD-ND/protein complex is stable, small and can be prepared with 1:1 stoichiometry following purification by gel electrophoresis. To show specific binding in live cells, we targeted a membrane receptor with an extracellular polyhistidine sequence expressed in HeLa cells. Finally, we applied our labeling strategy to record the movement of end binding protein-1 (EB1), a microtubule associated proteins in Xenopus cell extracts. EB1 is a $35 \mathrm{kDa}$ cytoplasmic protein known to specifically bind to microtubules and to regulate their dynamics. ${ }^{37}$ In this study, a purified histag EB1 was coupled to QD$\mathrm{ND}$ in vitro and applied to cell extracts. We monitored QDND/EB1 during the formation of the mitotic spindle, a

(29) Pellegrino, T.; Manna, L.; Kudera, S.; Liedl, T.; Koktysh, D.; Rogach, A. L.; Keller, S.; Radler, J.; Natile, G.; Parak, W. J. Nano Lett. 2004, 4 (4), 703-707.

(30) Pons, T.; Uyeda, H. T.; Medintz, I. L.; Mattoussi, H. J. Phys. Chem. B 2006, 110 (41), 20308-20316.

(31) Carion, O.; Mahler, B.; Pons, T.; Dubertret, B. Nat. Protoc. 2007, 2 (10), 2383-2390.

(32) Luccardini, C.; Tribet, C.; Vial, F.; Marchi-Artzner, V.; Dahan, M. Langmuir 2006, 22 (5), 2304-2310.

(33) Mei, B. C.; Susumu, K.; Medintz, I. L.; Delehanty, J. B.; Mountziaris, T. J.; Mattoussi, H. J. Mater. Chem. 2008, 18 (41), 4949-4958.

(34) Mei, B. C.; Susumu, K.; Medintz, I. L.; Mattoussi, H. Nat. Protoc. 2009, 4 (3), 412-23.

(35) Pinaud, F.; King, D.; Moore, H. P.; Weiss, S. J. Am. Chem. Soc. 2004, 126 (19), 6115-6123.

(36) Dif, A.; Henri, E.; Artzner, F.; Baudy-Floch, M.; Schmutz, M.; Dahan, M.; Marchi-Artzner, V. J. Am. Chem. Soc. 2008, 130 (26), 82898296.

(37) Schuyler, S. C.; Pellman, D. Cell 2001, 105 (4), 421-424. 

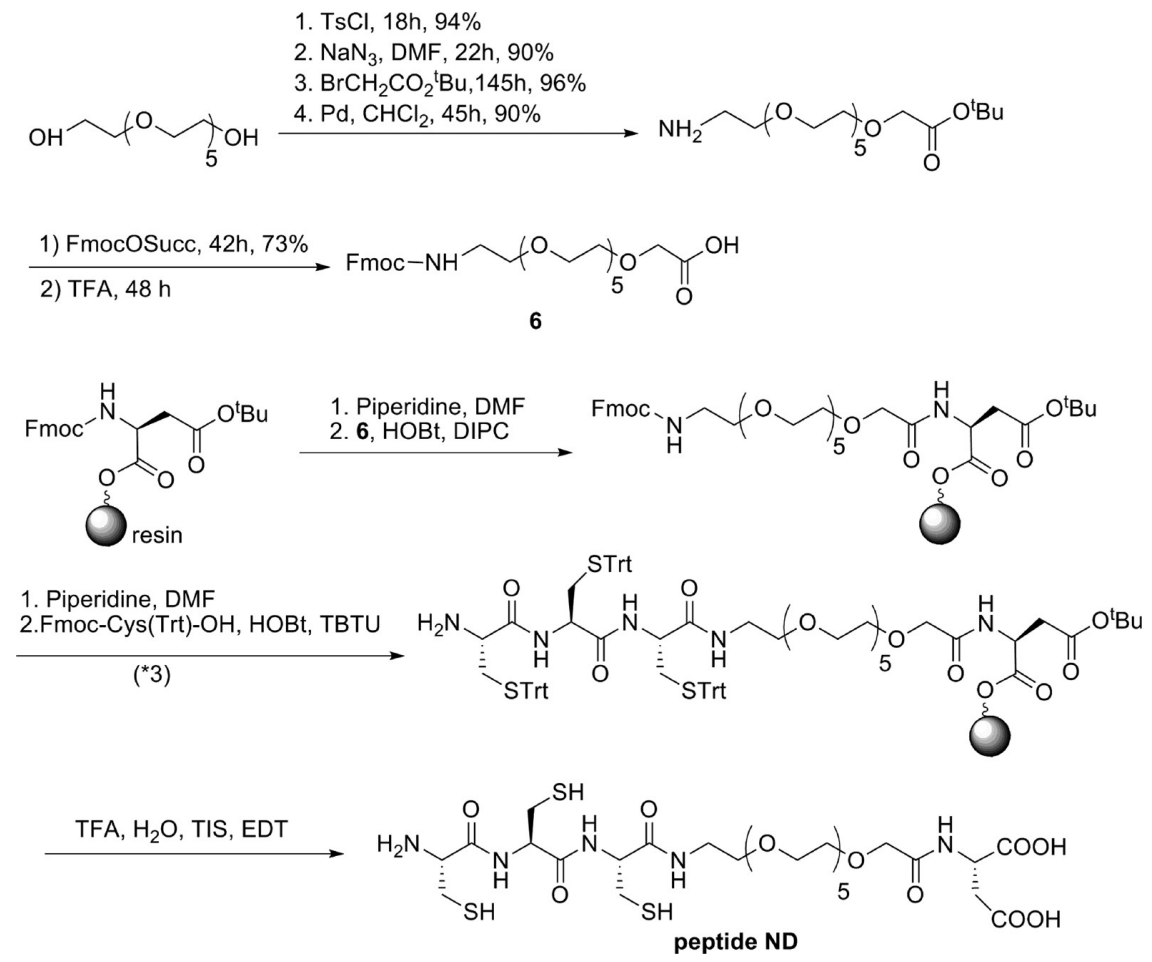

Figure 1. Synthetic route for the PEGylated peptide ND.

microtubule-based structure essential for cell division, ${ }^{38}$ and found that QD-ND/EB1 colocalized specifically with the spindle. Single molecule tracking allowed us to extract the velocity distribution of EB1 interacting with the microtubules. Variability observed in EB1 motion might reflect the various modes of the dynamics of the EB1/microtubule complex, illustrating the intrinsic dynamical heterogeneity of the mitotic spindle apparatus.

\section{Experimental Methods}

Synthesis of the Peptide Ligands (See Figure 1 for Reaction Scheme). All the reactants and solvents were purchased from Sigma Aldrich.

Hexaethyleneglycol Mono-p-toluenesulfonate 2. Potassium iodide KI (0.295 g, $1.78 \mathrm{mmol}, 0.1$ equiv), silver oxide $\mathrm{Ag}_{2} \mathrm{O}$ (4.95 $\mathrm{g}, 21.4 \mathrm{mmol}, 1.2$ equiv), and tosyl chloride were added to a solution of commercial hexaethylene glycol $(5.01 \mathrm{~g}, 17.8 \mathrm{mmol}, 1$ equiv) in anhydrous $\mathrm{CH}_{2} \mathrm{Cl}_{2}(178 \mathrm{~mL})$. The reaction mixture was kept at room temperature for $18 \mathrm{~h}$ and then filtrated on Celite. After solvent evaporation, the crude product was subjected to chromatography (silica gel $60 \mathrm{~g}$, elution with $\mathrm{AcOEt} / \mathrm{MeOH} 85 / 15$ ) to give the monotosylate 2 (7.25 g, $16.6 \mathrm{mmol}$, yield 94\%). ${ }^{1} \mathrm{H}$ NMR (200 $\left.\mathrm{MHz}, \mathrm{CDCl}_{3}\right): \delta=7.80(\mathrm{~d}, J=8 \mathrm{~Hz}, 2 \mathrm{H}), 7.34(\mathrm{~d}, J=8 \mathrm{~Hz}$, $2 \mathrm{H}), 4.18(\mathrm{t}, 2 \mathrm{H}), 3.75-3.58(\mathrm{~m}, 22 \mathrm{H}), 2.61$ (broad s, OH), 2.48 (s, 3H).

Hexaethyleneglycol Monoazide 3. 2 (7.25 g, $16.6 \mathrm{mmol}, 1$ equiv) and sodium azide were mixed in a solution of anhydrous DMF (36 mL). The mixture was kept at reflux for $22 \mathrm{~h}$ under argon. After DMF evaporation, the mixture was extracted with diethylether, and the organic phases were washed with brine. Drying over $\mathrm{Na}_{2} \mathrm{SO}_{4}$ afforded 3 (4.653 g, yield 90\%). ${ }^{1} \mathrm{H}$ NMR (200 MHz, $\left.\mathrm{CDCl}_{3}\right): \delta$ $=3.72-3.67(\mathrm{~m}, 22 \mathrm{H}), 3.41(\mathrm{t}, 2 \mathrm{H}), 2.78($ broad $\mathrm{s}, \mathrm{OH})$.

tert-Butyl 2-[Monoazide (Hexaethyleneoxy)]acetate 4. tertButylbromo acetate $(4.68 \mathrm{~g}, 24 \mathrm{mmol}, 1.6$ equiv), iron oxide $(0.49$ $\mathrm{g}, 0.2$ equiv) potassium iodide (5.21 g, 1.5 equiv) were added to a solution of 3 (4.653 g, $15 \mathrm{mmol}, 1$ equiv) in anhydrous $\mathrm{CH}_{2} \mathrm{Cl}_{2}$ $(50 \mathrm{~mL})$. The mixture was kept at room temperature for 5 days.

(38) Desai, A. Methods Cell Biol 1999, 61, 385.
After filtration on Celite and solvent evaporation, the crude product was subjected to chromatography (silica gel, eluent AcOEt/MeOH 90/10) to afford 4 (6.089 g, $14.5 \mathrm{mmol}$, yield 96\%). ${ }^{1} \mathrm{H}$ NMR (200 $\left.\mathrm{MHz}, \mathrm{CDCl}_{3}\right): \delta=4.05(\mathrm{~s}, 2 \mathrm{H}), 3.73-3.69(\mathrm{~m}, 22 \mathrm{H}), 3.41(\mathrm{t}$, $2 \mathrm{H}), 1.51(\mathrm{~s}, 9 \mathrm{H})$.

tert-Butyl 2-[amino (Hexaethyleneoxy)]acetate 5. A suspension of 4 (6 g, $14.5 \mathrm{mmol}, 1$ equiv) and $0.6 \mathrm{~g}$ of $\mathrm{Pd} / \mathrm{C}(10 \%$ in mass) in anhydrous $\mathrm{CH}_{2} \mathrm{Cl}_{2}(60 \mathrm{~mL})$ was stirred for $45 \mathrm{~h}$ under reduced pressure of dihydrogen. Filtration and solvent evaporation afforded $\mathbf{5}(5,09 \mathrm{~g}, 12.9 \mathrm{mmol}$, yield $90 \%)$ that was used without any further purification. ${ }^{1} \mathrm{H}$ NMR $\left(300 \mathrm{MHz}, \mathrm{CDCl}_{3}: \delta=4.05(\mathrm{~s}, 2 \mathrm{H}), 3.73\right.$ $-3.69(\mathrm{~m}, 22 \mathrm{H}), 3.95(\mathrm{t}, 2 \mathrm{H}), 3.22(\mathrm{t}, 2 \mathrm{H}), 1.50(\mathrm{~s}, 9 \mathrm{H})$.

2-[Fmoc-amino (Hexaethyleneoxy)] ]acetic Acid 6. $N$-(9-Fluorenylmethoxycarbonyloxy)succinimide (Fmoc-OSu) (1.97 g, 5.8 mmol, 2.33 equiv) was added to a solution of $5(0.98 \mathrm{~g}, 2.48 \mathrm{mmol}$, 1 equiv) in THF $(8.6 \mathrm{~mL})$ at $0{ }^{\circ} \mathrm{C}$. The reaction mixture was kept at room temperature for $42 \mathrm{~h}$. The crude product was subjected successively to two chromatographies (silica gel $90 \mathrm{~g}$, eluent AcOEt/ hexane $(50 / 50$ and $75 / 25))$ to give the protected amine $(0.85 \mathrm{~g}$, $1.82 \mathrm{mmol}$, yield 73\%). ${ }^{1} \mathrm{H}$ NMR $\left(300 \mathrm{MHz}, \mathrm{CDCl}_{3}: \delta=7.8(\mathrm{~d}\right.$, $2 \mathrm{H}), 7.64(\mathrm{~d}, 2 \mathrm{H}), 7.45(\mathrm{t}, 2 \mathrm{H}), 7.31(\mathrm{t}, 2 \mathrm{H}), 5.58(\mathrm{t}, 1 \mathrm{H}), 4.45(\mathrm{~d}$, $2 \mathrm{H}), 4.25$ (t, 1H), 4.05 (s, 2H), $3.72-3.66(\mathrm{~m}, 22 \mathrm{H}), 3.45(\mathrm{q}, 2 \mathrm{H})$, $1.50(\mathrm{~s}, 9 \mathrm{H})$. The carboxylic acid function was then deprotected with TFA to give 6, which was used as a classical protected Fmoc peptide.

Peptide ND Synthesis. Peptides were synthesized by classical Fmoc ( $N$-[9-fluorenyl]methoxycarbonyl) solid-phase chemistry and by using a commercial automatic peptide synthesizer by coupling Fmoc- $\alpha$-amino acids on preloaded Wang resin. ${ }^{36,39}$ Protected amino acids and 6 were coupled by in situ activation with $2-(1 \mathrm{H}-$ benzotriazole-1-yl)-1,1,3,3-tetramethyluronium tetrafluoroborate (TBTU) and $N$-hydroxybenzotriazole (HOBt). $\mathrm{N}^{\alpha}$-Fmoc deprotection was performed with $20 \%$ piperidine in DMF. Side-chain deprotection and cleavage of peptides from the solid support was performed by treatment with cleavage reagent $(94.5 \%$ trifluoroacetic acid (TFA) $/ 2.5 \%$ water $2.5 \%$ ethanedithiol (EDT)/\% triisopropylsilane (TIS)) for $2 \mathrm{~h}$ at $20^{\circ} \mathrm{C}$. Peptides were purified by reversed-

(39) Hyman, A. A. J. Cell. Sci. Suppl. 1991, 14, 125-127. 
phase HPLC (RP-HPLC) using a Waters semipreparative HPLC system on an X Terra $10 \mu \mathrm{m}$ column $(300 \mathrm{~mm} \times 19 \mathrm{~mm})$. The elution was performed with a gradient of aqueous $0.1 \%$ TFA (A) and $0.08 \%$ TFA in acetonitrile (B) at a flow rate of $10 \mathrm{~mL} / \mathrm{min}$ with a photodiode array detection at $210-440 \mathrm{~nm}$. The purity of each peptide was controlled by analytical RP-HPLC on the same instrument with an X Terra $5 \mu \mathrm{m}$ column $(250 \mathrm{~mm} \times 4.6 \mathrm{~mm})$ using a linear gradient of $0.1 \%$ TFA in water and acetonitrile containing $0.08 \%$ TFA at a flow rate of $1 \mathrm{~mL} / \mathrm{min}$. Finally, the peptide was analyzed by electrospray spectrometry. Peptide ND: Purity $85 \%, t_{\mathrm{r}}=12.48 \mathrm{~min}$. HRMS $[\mathrm{M}+\mathrm{H}]^{+}$calcd for $\mathrm{C}_{27} \mathrm{H}_{45} \mathrm{~N}_{5} \mathrm{O}_{14} \mathrm{~S}_{3}$ 764.25164, found 764.2523 (1 ppm).

Peptide 7. The control peptide $7\left(\mathrm{H}_{2} \mathrm{~N}-\mathrm{CCCSSSD}-\mathrm{OH}\right)$ was prepared according to our previous described method. ${ }^{36}$ Purity $85 \%$ $t_{\mathrm{r}}=12.48$ min. HRMS $[\mathrm{M}+\mathrm{H}]+$ calcd for $\mathrm{C}_{22} \mathrm{H}_{37} \mathrm{~N}_{7} \mathrm{O}_{13} \mathrm{~S}_{3}$ 704.16898, found 704.1688 (1 ppm).

Peptide Functionalization of QDs. Commercial core/shell CdSe/ ZnS QDs (Evidots, Evident Technology, $\lambda_{\mathrm{em}}=545$ or $605 \mathrm{~nm}$ ) were precipitated from initial toluene solution with methanol and dried under vacuum and then redispersed in a pyridine solution. Peptides ND or 7 were dissolved in anhydrous $99.8 \%$ dimethyl sulfoxide (DMSO), at a concentration between 10 and $30 \mathrm{mM}$. The QDs in pyridine and the peptide solution in DMSO were mixed together. After addition of tetramethylammonium hydroxide, aggregates of fluorescent QD-peptide were isolated by centrifugation during $30 \mathrm{~min}$ at $15000 \mathrm{~g}$. After removing the supernatant, the QDs were dried for $2 \mathrm{~h}$ and then redispersed in water. To remove the aggregated nanocrystals, this solution was ultracentrifuged at $100000 \mathrm{~g}$ during $30 \mathrm{~min}$ on a $50 \%$ sucrose cushion. The resulting sample was passed through a G25 spin column and dialyzed against pure water to remove sucrose and the excess of free peptide. Before using, the QD-peptide solution was filtered through a $0.22 \mu \mathrm{m}$ Millipore filter (Millex HV, Sigma-Aldrich).

EB1 Expression and Purification. Full-length H6-EB1 was expressed in BL21-PlysS cells (Novagen) and purified on nickelagarose beads. ${ }^{40}$ After dialysis against a sodium phosphate buffer, the proteins were flash frozen and stored at $-80{ }^{\circ} \mathrm{C}$ in aliquots.

Dynamic Light-Scattering (DLS) and Fluorescence Correlation Spectroscopy (FCS). The mean hydrodynamic diameters were obtained from a Nanosizer ZEN3600 (Malvern Instruments) DLS spectrometer (angle $90^{\circ}$ at $25^{\circ} \mathrm{C}$ ). All samples were filtered through $0.22 \mu \mathrm{m}$ Millipore filter. FCS measurements were performed on a home-built microscope equipped with an Olympus 60X water immersion objective (UPlan Apo, NA 1.2). Two-photon excitation ( $200 \mathrm{fs}, 76 \mathrm{kHz}, 750 \mathrm{~nm}$ excitation) was provided by a mode-locked Ti-Sapphire laser (Mira, Coherent). The incident power at the sample was measured with a Lasermate powermeter (Coherent). The fluorescence photons were collected through filters (AHF Analysentechnik) and optical fibers (FG200LCR multimode fiber, Thorlabs) and detected with avalanche photodiodes (SPCM-AQR14, Perkin-Elmer) coupled to an ALV-6000 correlator (ALV $\mathrm{GmbH}$ ). The geometrical characteristics of the focal point were determined using a fluorescein solution of known concentration (50 $\mathrm{nM}$ in $0.1 \mathrm{M} \mathrm{NaOH})$. FCS measurements were performed on aqueous QD solutions in the nanomolar range at $20^{\circ} \mathrm{C}$. Autocorrelation curves were well adjusted, assuming a single freely diffusing species in solution. In the case of two-photon excitation, the diffusion time $\tau_{\mathrm{D}}$ through the beam waist of size $\omega$ can be linked to the hydrodynamic radius $R$ of the diffusing species using the Stokes-Einstein relation by: $\tau_{\mathrm{D}}=3 \pi \eta R \omega^{2} / 4 k T$ where $\eta$ is the viscosity, $T$ the temperature and $k$ the Boltzmann constant.

Electrophoresis and Protein Coupling. QD-ND (200nM) was preloaded with $\mathrm{Ni}^{2+}(50 \mu \mathrm{M})$ for $15 \mathrm{~min}$, and then incubated with various molar ratios of histag EB1 during $1 \mathrm{~h}$. Gel electrophoresis of the different QD-ND/EB1 ratios was performed on a $0.5 \%$

(40) Tirnauer, J. S.; Grego, S.; Salmon, E. D.; Mitchison, T. J. Mol. Biol. Cell 2002, 13 (10), 3614-3626. agarose gel in in HEPES buffer ( $\mathrm{pH} 7.5$ ) under an applied voltage of $100 \mathrm{~V}$ for $30 \mathrm{~min}$.

Photophysical Properties. UV-vis spectra of QDs were performed on a Cary $100 \mathrm{UV}$-vis spectrophotometer (Varian). The QD diameters were evaluated from the maximum absorbance of the excitonic peak, and the extinction coefficient at $350 \mathrm{~nm}$ was calculated according to the literature (for QDs with emission at $\left.605 \mathrm{~nm}, \varepsilon=10^{5} \mathrm{~cm}^{-1} \cdot \mathrm{mol}^{-1}\right)$. Fluorescence spectra were measured on a Spectrolog 3 (Horiba Jobin Yvon) fluorimeter. ${ }^{41,42}$

Quartz Crystal Microbalance. The quartz crystal microbalance (QCM-D) experiments were performed on a Q-Sense D 300 apparatus (Q-Sense $\mathrm{AB}$ ) by monitoring the resonance frequencies of the gold-coated crystal at four different frequencies $(5,15,25$, and $35 \mathrm{MHz}$ ). These data give, in principle, information about the adsorption process as well as the mechanical properties of the deposited film. ${ }^{43,44}$ At the start, the crystal was put into contact with a buffer solution (Tris-borate- $\mathrm{NaCl}$ : TrisBase $0.89 \mathrm{M}$, boric acid $0.89 \mathrm{M}, \mathrm{NaCl} 0.20 \mathrm{M}$ ) for $10 \mathrm{~min}$. Next, a $0.5 \mathrm{mg} / \mathrm{mL}$ peptide ND solution was injected and left $50 \mathrm{~min}$ in contact with the sensor before three successive rinsing steps with the buffer. A solution of $\mathrm{NiCl}_{2}(1.5 \mathrm{mM})$ was then injected followed by EB1 solution $(0.07$ $\mathrm{mg} / \mathrm{mL}$ in buffer solution). After stabilization of the signal and a rinsing step with the buffer, EDTA solution $(2 \mathrm{mM})$ was injected.

Cellular Cytotoxicity MTT Assay. HeLa cell culture was performed in Dulbecco's modified Eagle's medium (DMEM) supplemented with $10 \%$ of fetal calf serum, $100 \mathrm{U} / \mathrm{mL}$ penicillin, $100 \mu \mathrm{g} / \mathrm{mL}$ streptomycin at $37{ }^{\circ} \mathrm{C} / 5 \% \mathrm{CO}_{2}$. The HeLa cells were seeded in 96 multiwell plates (500 cells per well, $100 \mu \mathrm{L}$ ) $24 \mathrm{~h}$ before adding the QDs. Then after growth medium removal, appropriate concentrations of QD-ND (filtered $0.22 \mu \mathrm{m}$ ) were added to each well. The typical protocol for MTT assay was as follows: A $5 \mathrm{mg} / \mathrm{mL}$ aqueous solution of MTT (methylthiazolyldiphenyltetrazolium bromide, Sigma Aldrich) was added to HeLa cells (10 $\mu \mathrm{L})$. After $4 \mathrm{~h}$ of incubation at $37{ }^{\circ} \mathrm{C} / 5 \% \mathrm{CO}_{2}$, the plates were centrifuged (5 min, $1000 \mathrm{rpm}$ ). After medium removal and addition of DMSO $(150 \mu \mathrm{L})$, the plates were stirred until complete dissolution of the purple formazan crystals. Finally, the absorbance at $540 \mathrm{~nm}$ was measured by a UV-vis plate reader (Labsystems Multiscan RC) driven by Biolise software. The absorbance was normalized using absorbance of control cells grown in nonmodified medium.

HeLa Cell Labeling. HeLa cells were transfected $24 \mathrm{~h}$ before labeling with the gene expressing the membrane protein H10-CFPTM, a transmembrane domain of platelet-derived growth factor receptor ${ }^{7}$ as previously reported. ${ }^{20}$ Cell labeling was performed by placing coverslips on a heating block at $37^{\circ} \mathrm{C}$. Cells were labeled with $20 \mathrm{nM}$ QD-ND by incubation in PBS for $10 \mathrm{~min}$ followed by repeated washing with PBS. HeLa cells were imaged at room temperature in OptiMem on an inverted wide-field epifluorescence microscope (Olympus, IX70) equipped with a $60 \times$ oil objective (NA 1.45, Olympus). Fluorophores were excited with a broadspectrum mercury lamp source. Images were acquired using a backilluminated CCD camera (Micromax 512EBFT, Roper Scientific) and MetaView software (Universal Imaging). H10-CFP-TM was imaged through a CFP filter set (excitation: $440 \pm 10 \mathrm{~nm}$, dichroic: $455 \mathrm{~nm}$, emission: $480 \pm 20 \mathrm{~nm}$ ). QD-ND was imaged through a custom filter set (excitation: $420 \pm 10 \mathrm{~nm}$, dichroic: $470 \mathrm{~nm}$, emission: $595 \pm 10 \mathrm{~nm}$ ).

QD Monitoring of Microtubules Self-Organization and Spindle Formation. Cytostatic-factor-arrested Xenopus laevis egg extracts were prepared as previously described. ${ }^{38}$ Tubulins, labeled

(41) Leatherdale, C. A.; Woo, W. K.; Mikulec, F. V.; Bawendi, M. G. J. Phys. Chem. B 2002, 106 (31), 7619-7622.

(42) Yu, W. W.; Qu, L.; Guo, W.; Peng, X. Chem. Mater. 2003, 15 (14), $2854-2860$.

(43) Marx, K. A. Biomacromolecules 2003, 4 (5), 1099-1120.

(44) Höök, F.; Vörös, J.; Rodahl, M.; Kurrat, R.; Boni, P.; Ramsden, J. J.; Textor, M.; Spencer, N. D.; Tengvall, P.; Gold, J.; Kasemo, B. Colloids Surf., B 2002, 24, 155-170. 
a<smiles>CC(CS)NC(=O)C(CS)OCNC(=O)C(CS)NC(=O)C(CS)NC(=O)C(N)CO</smiles>

Peptide ND<smiles>CSSCC(=O)NC(CO)C(=O)NC(CO)C(=O)NC(CO)C(CO)NC(CC(=O)O)C(=O)NC(CS)C(=O)O</smiles>
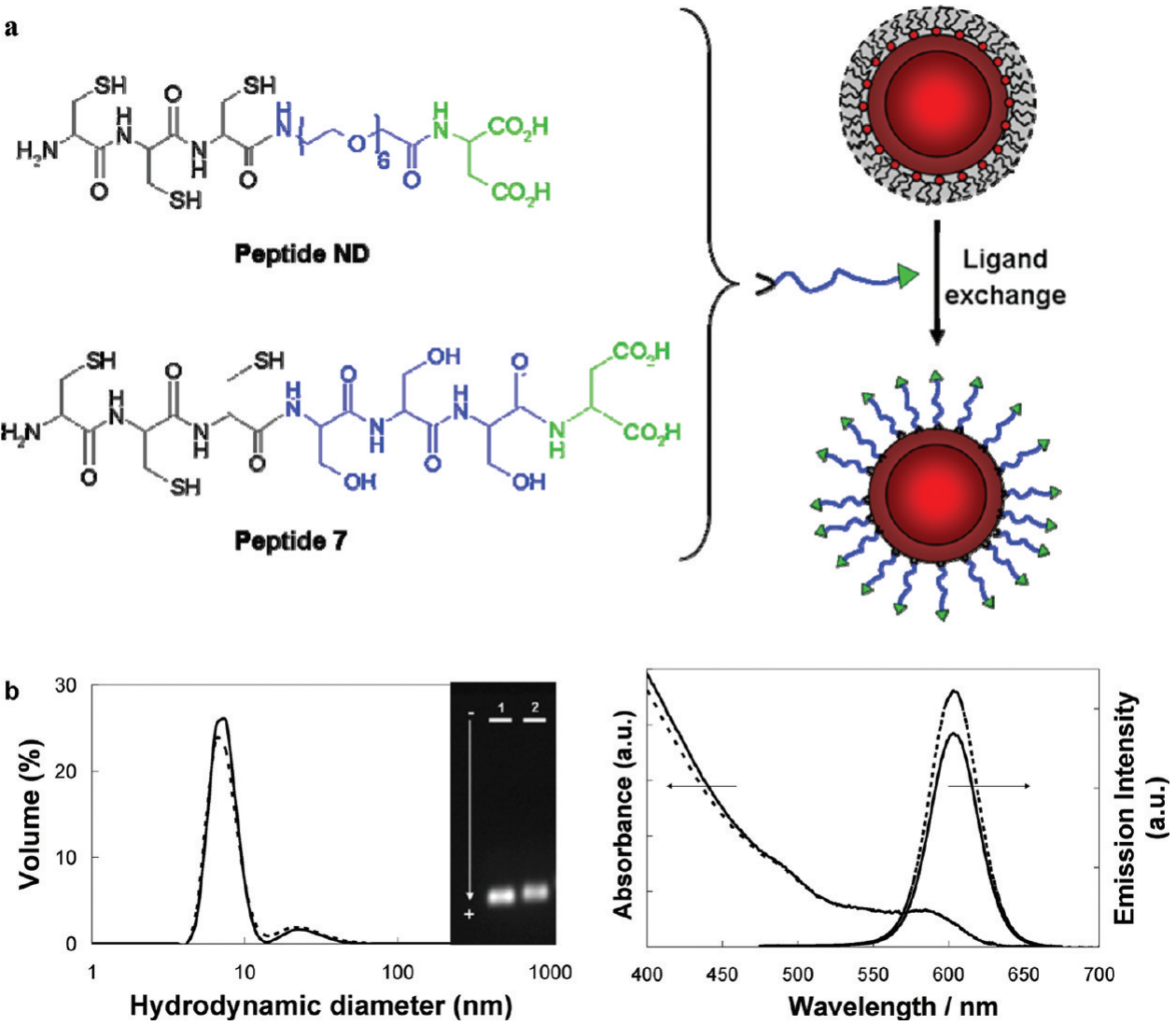

Figure 2. (a) Chemical structures of peptide ND and peptide 7. (b) (left) DLS volume distribution and (right) agarose gel electrophoresis of QD-ND before (1) and after (2) incubation with $50 \mu \mathrm{M} \mathrm{NiCl}_{2}$ and the corresponding absorbance/emission spectra of QD-ND before (solid line) and after incubation with $\mathrm{NiCl}_{2}$ (dashed line).

with X-Rhodamine (Molecular Probes) were prepared as previously described. ${ }^{39}$ The molar ratio between QD-ND and EB1 was 1:6. A solution of QD-ND/EB1 complex solution in the nanomolar range was incubated 15 min after the beginning of the spindle assembly process. Fluorescence imaging of microtubule spindles was performed using an IX81 (Olympus) equipped with either a X60 (Plan Apo, NA 1.42) or a X100 (Plan Apo, NA 1.4) objective, and an EM-CCD (C9102, Hamamatsu). Image analyses were performed using Image J Software (Scion Image) and Simple PCI software. The mean velocity was calculated from the image sequence of the individual QD-ND/EB1 collected during $20 \mathrm{~s}$ ( $N=87$ events). The motion of individual QDs was acquired with an integration time of $100-400 \mathrm{~ms}$ per frame.

\section{Results and Discussion}

For the purpose of stabilizing QDs in aqueous buffer and enabling the conjugation of histag proteins, the short PEGylated peptide ND was synthesized according to the scheme presented in Figure 1. At the N-terminal, a tricysteine serves as an adhesive sequence designed to bind to the QD surface. An aspartic acid, which is negatively charged at basic $\mathrm{pH}$, was grafted at the C-terminal to provide charge stabilization of the colloidal QDs in a variety of common buffers and at different $\mathrm{pHs}$ (see Figure $\mathrm{S} 1$ in Supporting Information). In addition, the aspartic acid was selected because of its expected ability to chelate metal ions and enhance the binding of histag proteins. Between the tricysteine and aspartic acid, a hexamer of PEG was introduced as a spacer to reduce nonspecific interactions and improve solubility. To obtain this compound, the PEGylated amino acid $\mathbf{6}$ was synthesized in several steps. Hexaethylene glycol $\mathbf{1}$ was first activated as the monotosylate $\mathbf{2}$ in the presence of a silver oxide catalysis and then converted into hexaethyleneoxy mono azide 3. After substitution of the free terminal alcohol with the tert-butylbromo acetate and azide reduction of $\mathbf{4}$, the bifunctional amino and protected carboxylic acid derivative $\mathbf{5}$ was obtained. The amino group was then protected with Fmoc succinimide. After deprotection of the carboxylic acid function with TFA, the resulted PEGylated amino acid $\mathbf{6}$ was first coupled to an aspartic acid preloaded Wang resin according to classical Fmoc ( $N$-[9-fluorenyl] methoxycarbonyl) solid-phase chemistry. Three cysteines were successively coupled by using a TBTU/HOBt activation. Finally after cleavage and deprotection, the peptide ND was obtained. To form a control peptide without the PEG spacer (peptide 7), the compound $\mathbf{6}$ was replaced by triserine spacer (Figure 2a).

To test the ability of the terminal aspartic acid in peptide $\mathrm{ND}$ to bind histag proteins via $\mathrm{Ni}^{2+}$ chelation, a surface-based assay was performed using a quartz crystal microbalance (QCM) and the protein histag EB1. The peptide ND was deposited on the gold-coated quartz microbalance via the strong interaction between cysteines and the gold surface. The adsorption and desorption of the histag EB1 proteins to the immobilized ND peptide in the presence or absence of $\mathrm{Ni}^{2+}$ ions was monitored (Figure S2 and Table S1 in Supporting Information). After preloading the ND peptide surface with $\mathrm{Ni}^{2+}$ ions, adsorption of the histag EB1 was enhanced by more than 3-fold compared to that in the absence of $\mathrm{Ni}^{2+}$ ions (Table $\mathrm{S} 1$ in Supporting Information). The addition of an EDTA competitor induced a desorption of about $46 \%$ of the adsorbed protein, indicating that a large fraction of the histag EB1 was bound through the $\mathrm{Ni}^{2+}$ loaded aspartic acid of the ND peptide. 
Table 1. Hydrodynamic Diameters of QD-ND before and after Incubation with 1 and 10 equiv of Histag EB1 Protein, As Measured by Fluorescence Correlation Spectroscopy (FCS) and Dynamic Light Scattering (DLS)

\begin{tabular}{cccc}
\hline $\begin{array}{c}\text { mean hydrodynamic } \\
\text { diameters obtained by }\end{array}$ & $0 n \mathrm{nEB} 1 / n \mathrm{nQ}$ & $1 \mathrm{nEB} 1 / n \mathrm{nD}$ & $10 \mathrm{nEB} 1 / n \mathrm{ND}$ \\
\hline FCS & $13 \pm 2 \mathrm{~nm}$ & $16 \pm 2 \mathrm{~nm}$ & $24 \pm 3 \mathrm{~nm}$ \\
$\mathrm{DLS}$ & $9 \pm 1.5 \mathrm{~nm}$ & $14 \pm 2.5 \mathrm{~nm}$ & $20 \pm 4 \mathrm{~nm}$ \\
& & & \\
\hline
\end{tabular}

Commercial semiconductor CdSe/ZnS QDs $\left(\lambda_{\mathrm{em}}=605 \mathrm{~nm}\right)$ were functionalized with the peptide ND or 7 according to a previously described method ${ }^{36}$ (see Figure 2a) based on ligand exchange between the initial trioctylphosphine oxide ligands of the hydrophobic QDs and the peptides. ${ }^{35}$ Water-soluble QDND exhibited a hydrodynamic diameter of $9 \mathrm{~nm}( \pm 1.5 \mathrm{~nm})$, determined by DLS and FCS measurements (see Table 1) and presented a high colloidal stability (over several months) in common buffers. During gel electrophoresis, the QDs migrated in a narrow band toward the positive electrode, which is consistent with their expected net negative charge (Figure $2 b$ ). The optical properties of the QDs were not altered after functionalization with the peptides, as shown from absorbance and fluorescence spectra (Figure $2 \mathrm{~b}$ ). ${ }^{36}$ In addition, the emission intensity was found to be stable between 6 and 12 and weakly affected until the $\mathrm{pH}$ reached 5 (see Figure S1 in Supporting Information). A strong quenching was then observed for acidic pHs (lower than 5). Therefore, the QD-NDs were found to be stable between $\mathrm{pH} 5$ and 12 . The effect of loading QD-ND with $50 \mu \mathrm{M} \mathrm{Ni}^{2+}$ was also minimal (Figure $2 \mathrm{~b}$ ), after optimizing the concentration and type of divalent cation (see Figure S3 in Supporting Information). The measured fluorescence quantum yield of the QD-ND was found to be around 25\% in water, which is an improvement over other peptide-based surface coatings. $^{35}$

Next, we tested the effect of the PEG spacer on nonspecific cellular interactions of the peptide-stabilized QDs. We monitored the adhesion of PEGylated QD-ND and non-PEGylated QD-7 toward living HeLa cells following incubation for $10 \mathrm{~min}$ and analysis by fluorescence microscopy (Figure 3). Nonspecific adsorption of the QD-7 on cell surface was present in high levels, indicated by the presence of QD fluorescence on the cell membranes, but was nearly completely inhibited by replacing the triserine spacer in 7 by the hexamer of PEG (case of QDND). Consequently, all the following experiments were performed with QD-ND.

The affinity of the QD-ND for histag proteins was then investigated in solution by following the interaction with DLS and FCS (Figure S4 in Supporting Information). A systematic increase in hydrodynamic diameter was observed for QD-ND, following incubation with increasing amounts of histag EB1 (Table 1). Considering the respective geometry of QD-ND and the $\mathrm{EB} 1$, the $10 \mathrm{~nm}$ increase in diameter observed for high ratios of the protein is in good agreement with the binding and steric saturation of the EB1 on the QD surface.

To provide further evidence of the conjugation between the QD-ND and the histag EB1, a titration of QD-ND with the protein was followed by gel electrophoresis. The addition of histag EB1 at various ratios to the QD-ND samples resulted in a systematic change in the QD migration patterns observed following electrophoresis (Figure 4a and Figure S5 in Supporting Information). QD-ND without EB1 migrated in a narrow, single band toward the positive electrode. However, in the QD-ND samples incubated with low ratios of EB1, discrete bands formed
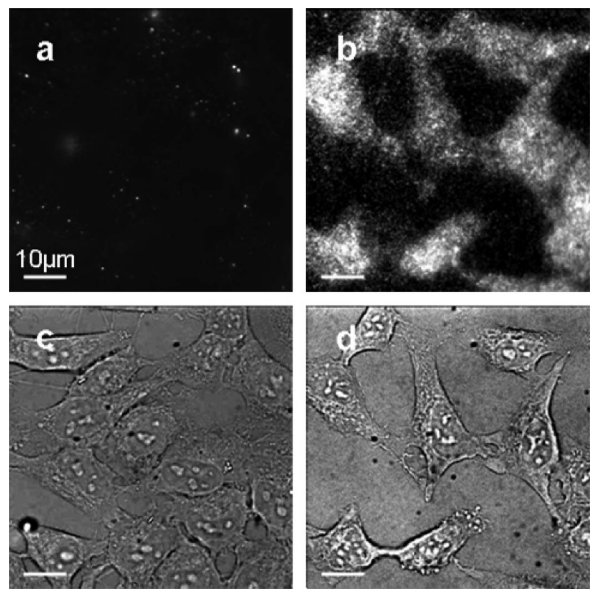

Figure 3. Fluorescence (top row) and bright field (bottom row) optical microscopy images of HeLa cells after a 10 min incubation with $100 \mathrm{nM}$ of QD-ND ( $\mathrm{a}$ and c) and QD-7 (b and d) followed by extensive washing.

in the gel corresponding to different stoichiometries of the QDND/EB1 complex (Figure 4a). At higher ratios of the protein, the sample merged again to a single band because of the steric saturation of the QD surface with EB1. ${ }^{30}$ On the basis of the ability to resolve these discrete bands in the gel, QD-ND containing exactly 1,2, and 3 copies of EB1 were isolated and purified by gel extraction. The temporal stability of the isolated complexes was high, because reanalysis of the purified 1:1 QDND/EB1 after several hours of storage showed that the complex maintained the expected position in the gel with respect to the unconjugated QD-ND (Figure 4b). Thus, small and stable QD/ protein complexes with defined stoichiometry could be prepared based on QD-ND.

In control experiments using gel electrophoresis, it was found that binding occurs between histag EB1 proteins and QD-ND without $\mathrm{Ni}^{2+}$ preloading of QD-ND (Figure S6 in Supporting Information). This suggests that there are multiple binding mechanisms between the histag sequence of the protein and QDND. The predominant mechanism is likely binding of the histag protein directly to $\mathrm{Zn}^{2+}$ ions on the $\mathrm{ZnS}$ shell of the $\mathrm{QD}$, owing to the highly compact nature of the peptide coating. Coincidently, this is the route of histag binding to QDs with similarly compact DHLA coatings. ${ }^{23,45}$ As suggested by our QCM surface assay, a secondary histag binding mechanism can occur through the aspartic acid chelated to $\mathrm{Ni}^{2+}$ ions, which may enhance the affinity of QD-ND to the histag.

To validate the use of the QD-ND in a biological system, we chose to probe the efficiency of our protein targeting system with living HeLa cells expressing a histag protein. As a first step, we designed an assay to determine the cytotoxicty of QDND. We used the colorimetric MTT assay to monitor HeLa cell viability as a function of both the QD-ND concentration and incubation time (Figure S7 in Supporting Information). No significant effect on cell viability was observed after one hour of incubation in the presence of QD-ND for concentrations ranging from 1 to $100 \mathrm{nM}$. A decrease in cell viability was seen only for incubation times exceeding $24 \mathrm{~h}$. In this case, relative cell viability decreased to $60 \%$ and $40 \%$ for QD-ND concentrations of $75 \mathrm{nM}$ and $100 \mathrm{nM}$, respectively. Similar results were observed when the QD-ND were preloaded with

(45) Pons, T.; Medintz, I. L.; Wang, X.; English, D. S.; Mattoussi, H. J. Am. Chem. Soc. 2006, 128 (47), 15324-15331. 
a

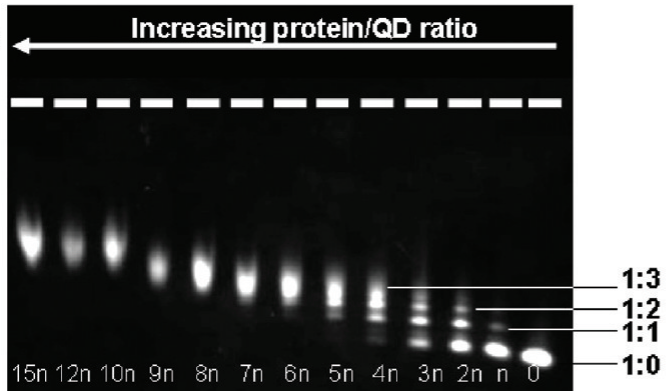

b

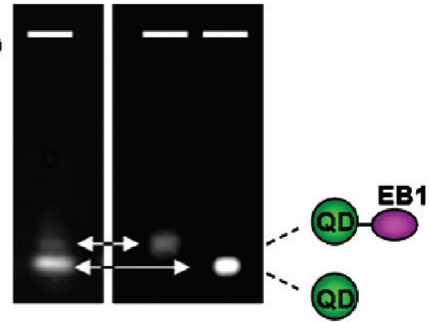

Figure 4. (a) Separation of QD-ND/EB1 complexes by $0.5 \%$ agarose gel electrophoresis. QD-ND loaded with $\mathrm{Ni}^{2+}$ was incubated with increasing concentrations of histag EB1 protein ( $n=1$ equivalent of QD-ND calculated from UV absorbance) for $1 \mathrm{~h}$ prior to loading and running the gel. (b) Gels of the QD-ND/EB1 complex before and after gel extraction and purification of the 1:1 QD-ND:EB1 stoichiometry.

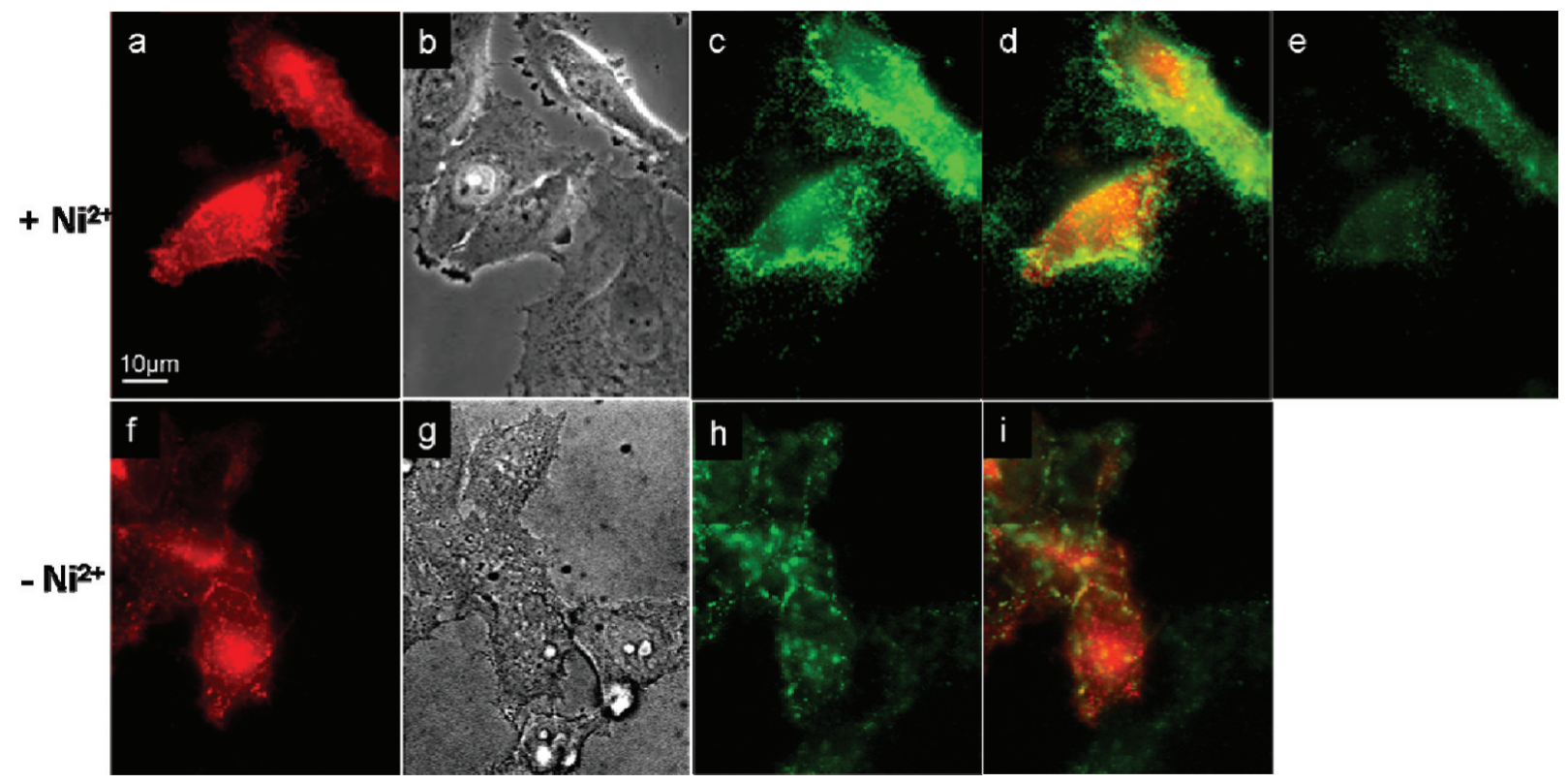

Figure 5. Fluorescence and bright field optical microscopy images of the HeLa cells expressing a transmembrane receptor incorporating an extracellular histag and CFP (H10-CFP-TM). Cells were incubated for $10 \mathrm{~min}$ with $20 \mathrm{nM}$ of QD-ND either in the presence (top row) or absence (bottom row) of Ni ${ }^{2+}$ loading. (a and f) CFP channel (red), showing the presence of cells expressing H10-CFP-TM. (b and g) Brightfield images of all the cells in the field of view. (c and h) QD-ND channel (green), showing the binding of QD-ND to cells expressing the H10-CFP-TM. (d and i) Superposition of the CFP and QD channels, showing the colocalization of the CFP and QD-ND signals. (e) QD-ND channel, after treatment of the cells with 100 mM imidazole showing the removal of the QD-ND from the cell surface.

$50 \mu \mathrm{M} \mathrm{NiCl}{ }_{2}$ before incubation in presence of the cells (see Figure S8 in Supporting Information). On the basis of these observations, QD-ND can be used for cellular labeling in nanomolar concentrations and for incubation periods up to one hour without affecting the cell viability.

Then, we investigated whether QD-ND can be used to target a specific protein on the membrane of the HeLa cells. HeLa cells were first transfected with the gene expressing the membrane protein H10-CFP-TM, having the transmembranar domain of platelet-derived growth factor receptor. ${ }^{7}$ The extracellular domain of the H10-CFP-TM includes a histag and a cyan fluorescent protein (CFP), which is used to identify cells expressing the protein. To target the H10-CFP-TM, 20 nM QDND was incubated with the cells for $10 \mathrm{~min}$ following by extensive washing with fresh medium. The cells were then examined by fluorescence microscopy. In the CFP channel, approximately $50 \%$ of the cells could be identified as expressing H10-CFP-TM (Figure 5a), while cells not expressing the protein were only visible under bright field illumination (Figure 5b). In the QD-ND channel, we observed QD-ND to be colocalized only on cells positive for H10-CFP-TM (Figure 5c and d). The diffusive movements of individual QD-ND bound to the H10CFP-TM could be observed as shown in Movie S1 (see Supporting Information). In addition, the QD-ND labeling of H10-CFP-TM was eliminated after the addition of free imidazole, a competitor of the histag (Figure 5e). Combined, these observations demonstrate that the interaction between the cells and QD-ND occurs via the specific histag sequence of the H10CFP-TM protein. The same experiment performed in the absence of $\mathrm{Ni}^{2+}$ loading also led to specific labeling of the $\mathrm{H} 10$ CFP-TM protein with QD-ND (Figure 5f-i), reinforcing our in vitro results that binding of histag proteins occurs predominantly at the $\mathrm{Zn}^{2+}$ surface of the QD.

To demonstrate that EB1 coupled to QD-ND remains biologically active, we monitored the interaction of the QDND/EB1 complex with microtubules during mitotic spindle formation. QD-ND/EB1 was prepared by mixing histag EB1 and QD-ND (using QD with an emission at $545 \mathrm{~nm}$ ) at a ratio of 6:1. We used Xenopus cell extracts, a system known to recapitulate key events of the cell cycle ${ }^{38}$ and well-suited to monitor microtubule morphogenesis dynamics. The absence of membrane boundaries in the cell extracts allows for direct 
a
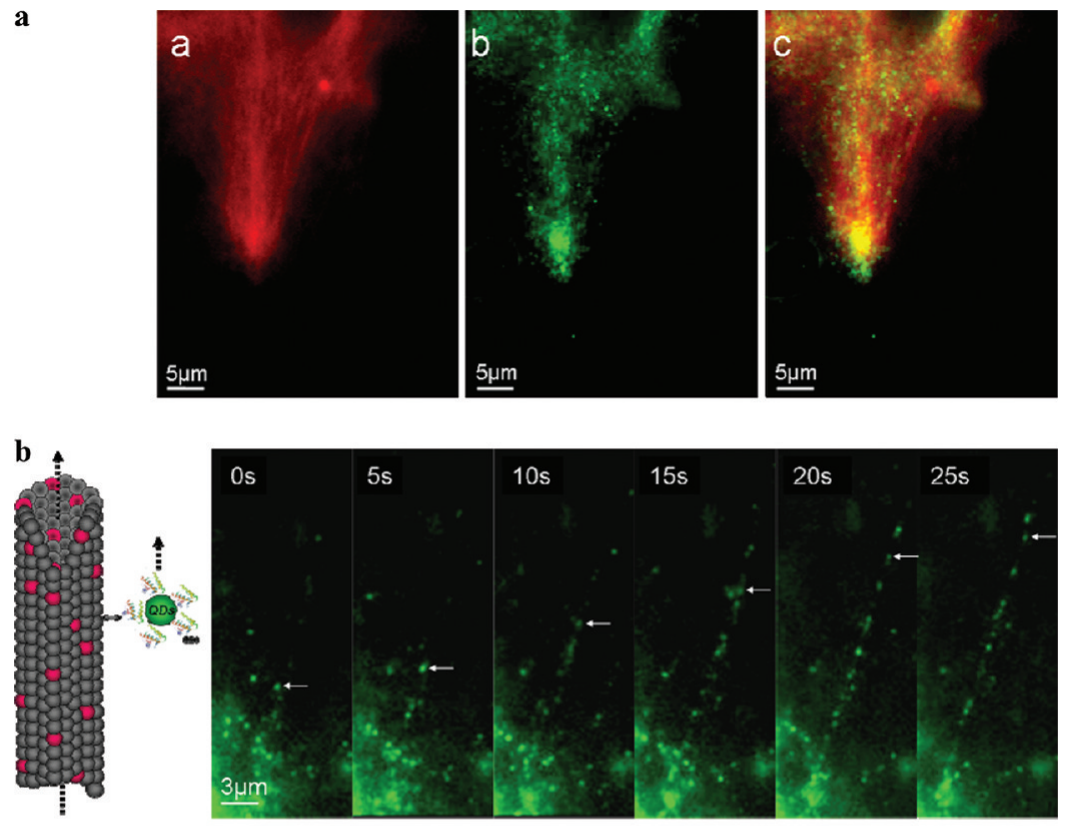

$15 \mathrm{~s}$

$20 \mathrm{~s}$

$25 \mathrm{~s}$

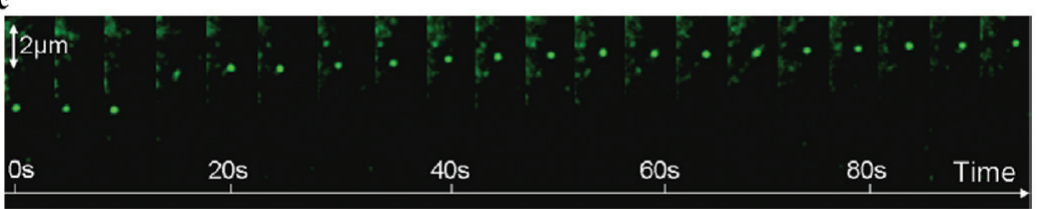

d

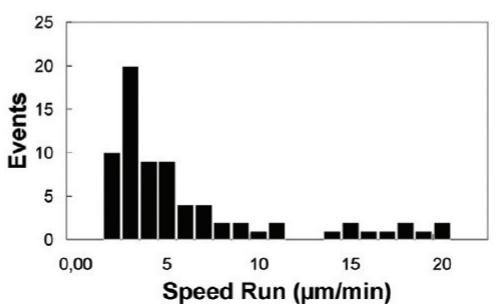

Figure 6. Specific targeting and tracking of QD-ND/EB1 on spindle structures following incubation of the QDs $\left(\lambda_{\mathrm{em}}=545 \mathrm{~nm}\right)$ with cell extracts. (a) Rhodamine-labeled spindle structure (red channel) with QD-ND/EB1 (green channel) and the overlay of the two channels (shown in yellow). (b) Temporal image sequence $(5 \mathrm{~s} /$ frame) of a single QD-ND/EB1 moving on a microtubule (see arrow). (c) Temporal sequence of a single QD-ND/EB1 (5 s/frame) on a microtubule exhibiting a switch between a fast and slow movement. (d) Mean velocity histogram extracted from a collection of individual QD-ND/EB1 moving on the spindle structures (3 independent experiments, 3 structures).

delivery of the QD-ND/EB1 in the cytosol without requiring endocytosis or microinjection. Rhodamine-labeled tubulin was initially supplemented to cell extracts to visualize microtubule filaments. The mitotic spindle self-organized to reach a steadystate structure within 30 to 45 min and the QD-ND/EB1 complex was applied $15 \mathrm{~min}$ after the initiation of the assembly. First, we performed static time-point measurements of samples at 30 and $45 \mathrm{~min}$. We found that microtubule bundles and QD-ND/ EB1 colocalized along microtubule based-structures (Figure $6 \mathrm{a}-\mathrm{c})$. The interactions between QD-ND/EB1 and microtubules were specific, as no colocalization between QDs and microtubule structures was observed when cell extracts were similarly treated with QD-ND lacking EB1 or QD-ND complexed with histag maltose binding protein (MBP), a protein which does not associate with microtubules ( $\mathrm{a}, \mathrm{b}$ and c,d, respectively, of Figure S9 in Supporting Information).

Next, time-lapse experiments were performed in order to monitor the QD-ND/EB1 dynamics within the microtubulebased structures. As shown in Movie S2 (see Supporting Information), most of the QD-ND/EB1 complexes that colocalize with the microtubule-based structures are dynamic. In
Figure $6 \mathrm{~b}$ and in Movie S3 (see Supporting Information), we report a time sequence of an individual QD-ND/EB1 complex performing a run of $13 \mu \mathrm{m}$ within $30 \mathrm{~s}$ along a growing microtubule filament. In another example highlighted in Figure 6c, the QD-ND/EB1 dynamics switched between fast motion and slower motion regimes. As EB1 binds preferentially to the plus-end of microtubules, ${ }^{37}$ the QD-ND/EB1 motion we observed reflects the dynamics of microtubule growth in the mitotic spindle.

The velocity histogram of individual events illustrates the heterogeneity of the dynamic QD-ND/EB1 behavior within the spindle structures (Figure 6d). Most dynamic events exhibit a mean velocity within the window of 2 and $5 \mu \mathrm{m} / \mathrm{min}$. Recently, single-molecule experiments performed with the yeast homologue of EB1 in a reconstituted system reported velocities between 2.5 to $10 \mu \mathrm{m} / \mathrm{min},{ }^{46}$ and tracking of clusters of EB1alexa594 within mitotic spindles reported an average velocity of $11 \mu \mathrm{m} / \mathrm{min}^{47}$ This variability observed in QD-ND/EB1 behavior might correlate with the dynamic properties of the mitotic spindle apparatus. For example, microtubules undergo rapid assembly, disassembly, and constant transport, providing 
multiple mechanisms to influence the dynamics. Both growing microtubules and rapid treadmilling of the tubulin dimers within microtubule filaments drive the observed QD-ND/EB1 dynamics. In addition, processive molecular motors may transport the QD-ND/EB1 complexes along microtubule filaments. These different modes of motion all reflect the complex and heterogeneous nature of the mitotic spindle assembly and maintenance cycles.

\section{Conclusion}

PEGylated peptides were found to stabilize CdSe/ZnS QDs in aqueous solution and to facilitate direct conjugation of polyhistidine-appended proteins with a controlled stoichiometry. This commercially available peptide offers an alternative way to label and target proteins with QD probes and can be extended to gold nanoparticles using the same functionalization methods. The obtained QD-ND-protein complexes were found to be very stable and of small size, which is highly desirable for cellular labeling. Additional advantages of this labeling approach are the simplicity of the conjugation to histag proteins, the control over the stoichiometry, and the reversibility of the binding in presence of competitors. One potential drawback of the method is the requirement of genetic engineering to introduce a polyhistidine sequence into the protein of interest. However, this has become routine practice in most laboratories, as the histag is now a standard method for protein purification.

Our QD-ND probe and labeling strategy was successfully applied to two different biological systems. First, we targeted a histag protein tethered to the external membrane of living cells. Then, we spatially and temporally monitored a microtububleassociated protein, EB1, within mitotic spindles assembled in cell extracts. Both systems demonstrate the ability of QD-ND for single-molecule tracking over long time scales not accessible by standard organic fluorescent labels. The possibility to target and study a variety of histag proteins, one at a time, should allow us to further understand how complex biological structures emerge from single-molecule events and maintain their integrity despite the transient and rapid turnover of their building blocks.

(46) Bieling, P.; Laan, L.; Schek, H.; Munteanu, E. L.; Sandblad, L.; Dogterom, M.; Brunner, D.; Surrey, T. Nature 2007, 450 (7172), 1100 1105 .

(47) Tirnauer, J. S.; Salmon, E. D.; Mitchison, T. J. Mol. Biol. Cell 2004, 15 (4), 1776-1784.
Acknowledgment. We thank J. S. Tirnauer for providing the plasmid of H6-EB1 as well as J. Piehler and A. Ting for the plasmid of the H10-CFP-TM. We are grateful to I. Arnal and D. Chrétien for fruitful discussions, and F. Chesnel and J. Kubiak for biological reagents. V.M.A. acknowledges financial support from the French Agency of National Research (ANR) (ANR-05-PNANO-045 and ANR-08-PNANO-050), the Région Bretagne and the Centre National de la Recherche Scientifique (CNRS). Z.G. acknowledges support from ANR (JC05_440006 and ANR-08-PNANO-050), CNRS and ARC (4474). R.L.B. acknowledges support from ANR (ANR-08-PNANO-050). M.D. acknowledges support from Fondation pour la Recherche Médicale (FRM), ANR (ANR-05PNANO-045) and the Human Frontier Science Program (grant RGP0005/2007). S.C. is supported by postdoctoral fellowships from Université Pierre et Marie Curie and the Fondation pour la Recherche Médicale.

Supporting Information Available: Figure S1: Effect of the $\mathrm{pH}$ on the fluorescence emission of the QD-ND. Figure S2 and Table S1: QCM binding experiments with histag EB1 and peptide ND. Figure S3: Fluorescence quenching effect of QDND due to the presence of different divalent ions. Figure S4: FCS and DLS of QD-ND in the presence and absence of EB1 protein, showing the size increase due to the formation of the QD-ND-protein complex. Figure S5: Gel electrophoresis of QDND in the presence of increasing concentrations of histag EB1 and small molar ratio of protein/QD in presence of nickel. Figure S6: Gel electrophoresis of QD-ND in the presence of increasing concentrations of histag EB1 without preloading with $\mathrm{Ni}^{2+}$ ions. Figures S7 and S8: Cytotoxicity MTT assay with QD-ND and HeLa cells as a function of the QD concentration and the incubation time with or without $\mathrm{Ni}^{2+}$ preloading of the QDND. Figure S9: Controls for the microtubule spindle experiments. Movie S1 showing the dynamics of the QD-ND bound to the histag transmembrane receptor at the surface of HeLa cells. Movie S2 and Movie S3 illustrating the dynamics of QD$\mathrm{ND} / \mathrm{EB} 1$ complexes interacting with the microtubule spindle in cell extracts. This material is available free of charge via the Internet at http://pubs.acs.org.

JA902743U 